\title{
A Study on the Problems of Migrant Women Workers in Thuvakudi, Trichy District
}

\author{
S.Srinivasan ${ }^{1}$, Dr. P. Illango, ${ }^{2}$ \\ 1 (Social Work, Bharathidasan University, Trichy, Tamil Nadu, India) \\ ${ }^{2}$ Head \& Professor Department of Social work, Bharathidasan University, Trichy.
}

\begin{abstract}
This research study focuses on Socio Economic Condition and problems of Migrant WomenWorkers. The migrant women workers face several problems such as low wages, health hazards, sexual exploitation and denial of their fundamental rights. Through this study the researcher aims to analyze the life of these migrant women workers. The specific objectives of the study are to identify the occupational, economic status, child care services available, health problems and exploitation faced by the women migrant workers and the expectations of the migrant women workers. The research design used for this study is descriptive. The sampling strategy used is simple random through lottery method. Data was collected from 100 respondents using an interview schedule by directly interviewing the respondents. The study reveals that Fifty eight percent of the respondents belonged to the age group of 20-40 years; Sixty five percent of the respondents are married. Perhaps their family commitments after marriage forced the married persons to work. Majority Ninety eight percent migrated within the state of Tamil Nadu, Seventy six percent of the migrated from rural to urban area because of poverty, unemployment, less wages in their native place. Eighty seven percent say that safety programmes are conducted to ensure the safety of the workers. Eighty seven percent say that they are not able to save money from their income. Forty six percent of the respondents were highly dissatisfied with their working conditions. Majority of the respondents Seventy six percent did not receive social security benefits such as maternity benefits. Sixty six percent of the respondents expect education, child care, proper housing facilities from the government and the agency. The existing Labour laws must be strictly enforced to save migrant women workers from exploitation and to receive their rightful wages. Making awareness of rights and policies of migrant workers women will definitely make a change in their lives in the future.
\end{abstract}

Key words: Women, Problems. Migrant, occupation, social security

\section{Introduction:}

Women are often described as the better half of man. Women's status has been argued as indicator of the level of development of particular societies. But today these assumptions are seriously under threat and actual condition of women in the world and particularly in developing countries like that of India, does not tally with these description. More than one million people in the world today, the great majority of who are women, live in unacceptable conditions.

In India the situation of women is worse especially the women migrant workers. Even after 61 years of its freedom more than $1 / 3^{\text {rd }}$ of the total population, still continues to live in abject poverty, lack of access to education, ill health, homelessness, unsafe environments and social discrimination and exclusion from the main stream. Women migrant workers are one of the most invisible and deprived groups of people. They have no voice for claiming any rights for help. The economic, social, cultural and political factors influence the decision to move.

According to the Indian constitution article 19 provides people basic freedom to move to any part of the country and the right to reside and earn a livelihood in the place of their choice. Poverty, unemployment and helplessness force people to leave their place of origin and to go to unknown places to work in extremely difficult condition

According to an estimate by the national commission on self - employed women 1988 of the total women workers about $94 \%$ are in informal unorganized sector alone, whereas just 6 percent of them are in the organized formal sector.

\section{The Importance of the Study:}

As the researcher is a student of social work specializing in community development is keen to understand the problems of women migrant workers. This will enable the researcher to take up some concrete work within the area later on after on after his studies. 


\section{Objective:}

1. To know the demographic details of the respondents.

2. To indentify the economic status of the respondents.

3. To find out the child care services available for women migrant workers.

4. To know the health status of the respondents.

5. To elicit the expectations and awareness of women migrant workers, to improve their conditions of life.

\section{Reasons For Migration:}

The factors which motivate migration may be called as push and pull factors.

Pull factors: the pull factors t hose which attract an individual to migrate.

Examples: employment opportunity, education, housing facilities etc.

Push factors: the push factors which motivate migration are poverty, indebtedness, social outcaste, unemployment, natural calamities etc. Which compete people to move out.

The others factors: the physical condition of a region which varies according to time and space play vital role in influencing human migration from one region to another.

Physical catastrophes such as earthquakes, landslides, climate fluctuation etc, have time to time influenced migration. Floods, droughts force people to desert their place of origin in favour of safer areas.

Economic factors: the important motivating factors are economic in search of better occupation, lack of cultivable land and growth of population. Prior to industrialization village cottage industries, and mechanization of agriculture made people to migrate.

Social factors: the number of deserted women is on the increase which leads to an increase in the migration of these women in search of livelihood.

According to All India data a higher percentage of women migrating from rural - rural destinations compared to rural - urban destinations. The male migrants are dependent on female earnings till they find work.

The social customs, tradition, induce people to migrate from one place to another. Inter caste marriage is an example. They are either socially outcastes or disliked the fellow villagers and relatives.

Demographic factors: the growth of population and unbalanced growth of literacy are other important factors. People with higher education and work experience move to new areas for their better earnings. The birth rate and the death rates also influence human migration. The increases of population leads to increase of labours, and the surplus labour from rural areas migrate to urban areas.

\section{Field of the Study:}

The study was conducted in Thuvakudi in Trichy district of Tamil Nadu. There are approximately 125 women migrant workers who are here as community for more than 3 years. The women migrant workers live under very poor conditions and they witnessed many problems such as discrimination, denial of their rights, sexual exploitations no security and safety in work place.

\section{Research Design:}

The research design used in this study is exploratory cum descriptive design. It is exploratory because the study is the first kind on women migrant workers. The researcher has made an attempt to explore the various problems of women migrant workers. At the same time it is descriptive as it describes the socio - economic and health condition of the women migrant workers.

\section{Statement of the Problem:}

Women migrant workers at Thuvakudi in Trichy, district live as a community and facing several problems such as low wages, health hazards, sexual abuse, exploitation and denial of their rights. They are exploited by the supervisors at work place. Their children do not get proper child care and medical facilities. The women migrant workers do not have proper quarters for staying.

\section{Sampling:}

The sampling technique adopted for this study was the simple random sampling, through the lottery method. The respondents were selected out of the one twenty five women migrant workers in this area. All the one twenty five women migrant workers were given numbers and the numbers units folded, put in a box and 100 were selected for the study. 


\section{Tool of Data Collection:}

The tool of data collection used for the study was an interview schedule. The interview schedule was prepared with the consultation of the research guide and based on the literature available of the topic. The interview schedule consists of personal data, working and living conditions, availability of child care services and utilization of government schemes.

\section{SOURCES OF DATA:}

The data was obtained from two sources.

\section{Data Collection:}

The primary data were collected from the respondents by using an interview schedule.

The secondary data was collected from books, news papers, websites, journals and resource persons.

\section{Limitation of the Study:}

The respondents who were available and willing to cooperate were chosen for the study. Among the migrant women workers, the quarry workers, constructions workers and sweepers were selected for the study. The other category of women migrant workers such as road laying, agricultural labourers, pavement vendors were not included for the study.

\section{Hypothesis:}

The research has assumed that the women migrant workers have a very poor and low standard of living and are vulnerable and can be subjected to lot of exploitations.

\section{Main Findings:}

Most of the women migrant workers (40\%) considered for the purpose of study were in the age of 21 to 30 years which is the early - adulthood stage in life. Among the sample selected for the study, merely 50 percent of the women were illiterate, while 24 percent of the women migrant workers had reached primary schooling level. This reveals that educational level of women migrant workers is very low. From the study it is evident that up to 60 percent of the respondents were married and were living with spouse. And only 20 percent of the women migrant workers were unmarried which reveal that migration is high among the married women workers. The study shows that $(60 \%)$ majority of the respondents were Hindus. This is in keeping with the country's majority of population. In spite of Christian NGO working in the area majority $(60 \%)$ is Hindus which means it shows that the Christian Ngo works for all women migrant workers irrespective of their religion. The findings describes that 56 percent of the respondents were migrated 15 years to Thuvakudi. Thirty four percent of the respondents were migrated before 5 to 10 years. In spite of being migrated to Thuvakudi for better prospects their Socio - Economic status had not improved.

The research study carried out by the researcher presents that the women migrant were from the nearby districts of Tamil Nadu. It is evident that they had migrated in search of livelihood to the nearby states. The women migrant workers considered for the purpose of this study were quarry workers (68\%), the majority of women workers were engaged in quarry work. Fifty two percent of the respondents were engaged in their occupation for 5 to 10 years and 44 percent for the respondents was engaged for 11 to 20 years. From the study it is seen that though the women migrant workers were engaged in their occupation for many years they do not have adequate earnings to support their families.

From the study it is seen that the distribution of respondents by their response towards the reality of the satisfaction of work is very minimum. 46 percent of the respondents were highly dissatisfied with the work they did, and nearly only 8 percent of the respondents were highly satisfied by the work they were engaged. This is very indicative of the fact that majority of the respondents were not happy with their work and they continued the work without any other option. Fifty percent of the respondents had yearly family income of Rs. 10000 to 2000 , only 2 percent of the respondents had family income more than Rs. 4000 per year. It clearly indicates that the family income of the respondents per year is inadequate in a fast growing consumerist society.

56 percent of the respondents had amount of Rs. 3000 to 5000 as savings while 34 percent of the respondents did not have the habit of savings. The respondents deposited the amount in the bank so that they could readily withdraw from the bank for future purposes. The study describes that 58 percent of the respondents had treatment in private hospitals, 26 percent of the respondents had taken treatment in clinic and only 16 percent of the respondents had treatment in government hospitals. Though the government hospitals provided free services of treatments, a majority of the respondents stated that they had no faith in the services rendered by the government hospitals. 
From the study it is evident that 78 percent of the respondents said that there was no child care centers present in the locality, only 22 percent of the respondents said that there were child care centers present in their locality. The presence of child care centers at locality of the respondents shows the quality child care service and the absence of the child care centre represents the lack of quality child care by the Government and the local NGO. 74 percent of the women migrant workers worked for more than 8 hours. Is high demand of long working hours by supervisors would lead to many problems for women workers such as menstrual flow. The study shows that 76 percent of the respondents had no holidays while only 24 percent of the respondents could get holidays. The demand of work without holidays and unrest is against the labour laws and which also leads to psychological problems of stress and health related problems.

56 percent of the respondents did not prefer to continue their work and only 8 percent of the respondents were willing to continue the same occupation. The majority (56\%) of unwillingness shows that there were no adequate provisions provided by the supervisors at work place. Majority of the respondents (80\%) had no accommodation within the work site by the supervisors. Only 20 percent of the respondents had been provided accommodations near the work place. The non - provision of accommodation leads to the delay in work by the women migrant workers who were coming from far distances. It is inferred from the study that majority of women workers suffered from body pain (62\%) due to breaking of stones in quarry and carrying of stones at work place.

The majority $(40 \%)$ depicts that there is no safety measures at work place. Non safety measures guarantees no safe life for the respondents. The study shows that 52 percent of the respondents' problems were not heard by the supervisors. This clearly describes that the majority of the problems of the respondents neither were nor ratified by the supervisors which showed the irresponsibility of the supervisors. It is observed form the study that almost all the respondents faced health that required immediate attention. It was found from the study that the majority (66\%) of the respondents surfed form depression and stress, 24 percent of the respondents surfed from shivery due to heavy and long hours of work. These factors show the prevalence of high rate of mental illness and they required psychological counselling services.

Since the women workers were migrants, they were deprived of their rights. 68 percent of them did not have ration cards and 64 percent of them did not have right to vote as a citizens. From the analysis of the study it is evident that majority 76 percent of the respondents did not receive any social security benefits during illness, 64 percent of the respondents were denied of maternity benefits during maternity. The majority of the respondents $(80 \%)$ did not receive the welfare measures due to not being aware of the schemes that were provided by the Government through the unorganized sector. Though the NGO is working for the women migrant workers at the local level for past ten years, the majority (60\%) of the respondents have not received any benefits from the NGO for their improvements of the life.

\section{Suggestions And Conclusion:}

The migration of women workers cannot be stopped, so the sufficient awareness must be provided about the schemes of the government that benefits the women such as nation maternity benefits and social security schemes. The NGO at locality can implement these programmes. From the research study it was found that the literacy level of women migrant workers was very low. Hence the NGO must take up literacy awareness campaign programmes. So that the women migrant workers can be aware of their rights and it can also help their children to avail proper formal education.

The women migrant workers have been living at Thuvakudi for more than 15 years and have no economic security to support their families. There must be economic welfare schemes to provide social and economic security to these women by the Government. The saving habits should be encouraged to the women workers and their spouses by the NGO which can protect them from the clutches of exploitative money lenders. The present study reveals that majority of the women migrant workers do not breastfeed their child. Therefore an improved child care service by the Government is the need of the hour. It should also ensure that the employers give due time during the working hours for breastfeeding. The local NGO can organize breastfeeding week to ensure quality child care.

It is indentified through the study that the presences of ICDS centers are rare. It should be established near the work spot of the migrant workers. They must function according to the timings of the migrant laborers' work. This can be done by the Government. It was observed from the study that availability of appropriate medical help is needed for the migrant women workers. For that health facilities should be provided through organizing medical camps periodically by the NGO. The women migrant workers are deprived of ration cards of voter ID due to their nature of migration. Temporary ration cards can be provided by the Government which can enable them to get goods for subsided rates. The Government should ensure provisions of services such as drinking water, proper housing, education, child care to ensure their rights.

It is found through the study that women migrant workers are denied of social security benefits under labour laws. So government must enact laws to protect the interest of the migrant workers. They must be saved 
from exploitation and must receive rightful wages and working conditions. The NGO at locality along with Government should initiate programmes for the improvement of the migrant women workers and their services should be extended to all women migrant workers. NGO at local should come forward to help women migrant workers to form an association to train them for leadership roles.

\section{Conclusion}

As women migrant workers are deprived and denied of their rights, there is an urgent need and attention to be paid to empower them through skills and vocational training who have no voice for claiming any right $s$ for help and vulnerable to all forms of exploitations. The study reveals that the women migrant workers must be empowered and above all they must be seen as unique personalities to treat them with respect and to uphold their dignity. The findings of the study by the researcher will pave a way for Gramodaya (NGO) to work for the betterment of the women migrant workers at Thuvakudi in Trichy district.

\section{References:}

[1] Alison Crosby, (2007). - People on the Move: Challenging migration on NGOs, migrants and sex work categorization, $\square$ Vol 50, p. 44-49.

[2] Aliyu AA, AU Shehu, (2006). —Occupational hazards and safety measures among stone quarry workers in northern Nigeria, $\square$ Nigerian Medical Practitioner, Vol. 50 (2) p. 42-47.

[3] Amrit Patel, (2010). "Empowerment of Rural Women Concern and Commtment

[4] of Elected Women Representatives, $\square$ Ministry or Rural Development, Kurukshetra, Vol.58 No. 8, p. 52.

[5] Anchal Singh \& Monica Srivastava, (2010). "Women Reservation Bill- Is It A Moe of Empowerment of Just Another Reservation, $\square$ Ministry or Rural Development The Monthly Journal, Kurukshetra, Vol.58 No. 8, p. 52.

[6] Anita J. Gagnon, Lisa Merry, Jacqueline Bocking, Ellen Rosenberg \& Jacqueline Oxman-Martinez, (2009). -Asian migrant women and HIV/STIs: Knowledge, attitudes and practices and the role of sexual power, $\square$ Published by UK Consortium on AIDS and International Development.

[7] Anupam Hazra, (2010). - The Women Reservation Bill: Can We Hope For Gender Equality, $\square$ Ministry or Rural Development, Kurukshetra, Vol. 58 No. 8 p. 52.

[8] Arianne Gaetano (2008). - Sexuality in diasporic space: rural-to-urban migrant women negotiating gender and marriage in contemporary China, $\square$ Published in- Gender, Place \& Culture Volume 15, Issue 6, p. $629-645$.

[9] Asha Bajpai (1997). - Women's Rights at the Workplace (Part I) \& (Part II ), Lawyer's Collective, $\square$ Tata Institute of Social Sciences, Mumbai, Vol.12, 10th, p.17-18 \& p. 13-16.

[10] Barkha Tandon (MS) \& Singh. D.K, 2007, Rural Migration in India, status and director, Kurukshetra, pp.23-27.

[11] Basu, Nighat (1987). — Rights of Married Women and Attitudes towards them: An Evaluation of Awareness and Attitudes, $\square$ Indian Journal of Adult Education, Vol.48 (2), p. 44-50.

[12] Bhat G.M. (1987). —Role of Women in Agriculture; A study of Kiser Valley of Jammu and Kashmir State, $\square$ Agricultural Situation in India, Vol.42 (2), p. 93-97.

[13] Darshan singh, 2005 Strategies for Empowering Women Workers, Social Welfare, May pp. 7 - 12.

[14] Deepak Nayyar, (1994). - Migration, Remittances and Capital Flows, $\square$ Oxford University Press, Bombay, Calcutta, Madras, Delhi.

[15] Futatsuka M, Shono M (2005). "Hand Arm Vibration Syndrome among Quarry Workers in Vietnam, $\square$ Journal of occupational health, Journal of occupational health Vol. 47(2), p. 165-170.

[16] Gupta, Pratibha, Sumedha, Sexana, (2004). - Ventilatory Lung Functions in Stone Quarry Workers of Rajasthan, $\square$ Vol 15- Issue $4-$ p. S162.

[17] Isabel Isidro, Rego, G. Camblor, C. Quero, A. González, A. Rodríguez, C (2004),

[18] Jodi Tuck, (2005). - Research with Migrant Women through Focus Groups Luciana Ruppenthal, School of Nursing, $\square$ Western Journal of Nursing Research, Vol. 27, No. 6, p. 735-754.

[19] Jeyan. K.N \& Sindhu Sadanandam, 2003, Rrual - Urban Migration and the Informal Sector in India, Kurukshetra, April, pp. 39 44.

[20] Joshi, Sneha \& Pushpanadham K. (2001). "Empowering women for educational management, $\square$ University news, Vol 39, No: 4, p.1-4.

[21] Kishwar, Madhu, (1992). —Sex Harassment and Slander as weapons of subjugation, $\square$ Manushi, No.62, p. 2-15.

[22] Lakshmi G.R. \& Bandyopadhyay S.S (1986). - Effect of Education, Economic Status and Occupation on Fertility, Health and Population $\square$ Vol 9 (1), p. 4251.

[23] Latika Sarka, (1994). —Rape: A human rights versus a patriarchal interpretation, $\square$ Indian journal of gender studies Vol I (1)p. 69.

[24] Louise Ryan, (2007). - Migrant Women, Social Networks and Motherhood: The Experiences of Irish Nurses in Britain, Sociology, $\square$ Vol. 41, No. 2, p. 295-312.

[25] Majid. A (1986). - Women's Contribution to Household Income among Agricultural Labourers of Punjab, $\square$ Agricultural Economics Research Centre, University of Delhi,

[26] Maureen Kilkenny (1993). —Rural/Urban Effects of Terminating Farm Subsidies, $\square$ American Journal of Agricultural Economics Published by Blackwell Publishing on behalf of the Agricultural \& Applied Economics Association Stable URL, Vol. 75, No. 4, p. 968-980.

[27] Mishra, Sweta,(1997). —Women and 73 rd Constitutional Amendment Act: A Critical Appraisal, $\square$ Social Action, Vol.44, p.1630.

[28] Mita Majumdar, (1991). —Rural women and Modernization, $\square$ Social Action, Vol.41, 1991, p. 367-381.

[29] Mohan Advani, (1996). —Urbanization, Displacement and Rehabilitation, $\square$ New Delhi, Jaipur, Rawat Publication.

[30] Ng TP, Phoon WH, Lee HS, Ng YL, Tan KT, (1992). "An epidemiological survey of respiratory morbidity among granite quarry workers in Singapore: chronic bronchitis and lung function impairment, $\square$ Ann Acad Med Singapore, Vol 21, p. 312-317S.

[31] Nirmala Banerjee \& Swasti Mitter, (1998). — Women Making a Meaningful Choice — Technology and New Economic Order, $\square$ Economic and Political Weekly, Vol. 33, No. 51, p. 3247-3256. 
[32] Olusegun O, A Adeniyi, GT Adeola, (2009). "Impact of Granite Quarrying on the Health of and Nearby Residents in Abeokuta Ogun State, Nigeria, $\square$ Vol 2, No 1, p. 21-26.

[33] Patnaik S.C \& Sailala Debi, (1986). - Assessment of Women's Economic Contribution to the Farm Sector: A Micro Level Study, $\square$ Journal of Rural Development, Vol 5(4), p. 480-490.

[34] Puri M, Cleland. J (2007). - Exploring the Nature and Reasons for Sexual Violence Within Marriage Among Young Women in Nepal, $\square$ Journal Of Interpersonal Violece, Vol 22 Issue: 11, p. 1363-1381.

[35] Ramsh .D, 2004: Outmigration of Labour from Rural areas: A Study, Kurukshetra, June, pp.28 - 33.

[36] Rao M.S.A, (1986). - Studies in Migration: Internal and International Migration in India, $\square$ Ramesh Jain for Manohar Publications, Delhi.

[37] Sammiah. M \& Mahavi. K.2005, Rights of Unorganized Women Workers, Joural of Social Welfare, May pp $3-6$.

[38] The Indian Journal of Social Work, Volume 59, issue - 3 July, 1998, Special issue, Women and Migration, TISS, Mumbai

[39] Sakakibara H, Miyao M, Nakagawa T, Yamada S, Kobayashi F, Ono Y, Iwata M, Hiragana N, Momoi N, Sangyo Igaku, (1984). -Vibration hazards in quarry workers, $\square$ Vol $26(2)$, p.170-6.

[40] Salih R, Routledge, (2001). "Moroccan migrant women: Transnationalism, nation-states and gender, $\square$ Jarnal of Ethnic and Migration Studies, Vol 27, No 4, p. 655-671(17).

[41] Santosh Nandal, (1993). "Women workers in unorganized sector: A study on construction industry in Haryana, $\square$ International Journal of Development Issues, Emerald Group Publishing Limited, Vol. 5 Iss: 2, p. 119 - 132.

[42] Shaojun Ma,(2010). "Beijing Center for Disease Control and Prevention, Beijing, China, Smoking Knowledge, Attitudes and Behaviors Among Rural-to Urban Migrant Women in Beijing, China, Asia Pacific Journal of Public Health, Vol. 22, No. 3, p. 342-353.

[43] Sin, D.P, (2005). - Women Workers in Unorganized Sector, $\square$ Deep \& Deep Publications Pvt, Ltd. New Delhi.

[44] Sinha V.N.P, Ataullah. MD, (1987). — Migration: An Interdisciplinary Approach, $\square$ Published by Seema Publication, Delhi.

[45] Sivaramayya. B, (1983). - Status of Women and Social change, $\square$ Journal of Indian law institute, Vol. 25, p. 270.

[46] Subba Rao P. And Lakshmi narayna Redd. K (1987). —Wage Discrimination against Women, Productivity, $\square$ Vol 28 (1), p. 73 78 .

[47] Subodh Dhawan, (2010). —On Being A Woman, Ministry or Rural Development, $\square$ The Monthly Journal, Kurukshetra, Vol.58 No. 8, p. 52.

[48] Sue Jackson, (2010). - Learning tllhrough social spaces: migrant women and lifelong learning in post-colonial London, $\square$ International Journal of Lifelong Education, Vol 29, Issue 2, p. 237 - 253.

[49] Sukla Deb Kanungo (1993). —Dalit women's search for identity, $\square$ Social Action, Vol.43, p. 481-494.

[50] Sunita Pathania, (1996). - Women's Movement in State of Haryana : Problems and challenges, $\square$ Women's Studies Research Centre, Kurukshetra University, Haryana, Social Action, Vol.45, p.163-177.

[51] Tripathy (S.N), (1996). - Unorganized Women Laborers in India, Discovery Publications, New Delhi.

[52] Ugbogu O C, J Ohakwe, and V Foltescu, (2009). - Occurrence of respiratory and skin problems among manual stone-quarrying workers, $\square$ Mera: African Journal of Respiratory Medicine. 